SHS Web of Conferences 2, 00039 (2012)

DOI: $10.1051 /$ shsconf $/ 20120200039$

(C) Owned by the authors, published by EDP Sciences, 2012

\title{
Deficiency of employability capacity
}

\author{
L. Vilka and I. Pelse
}

Rīga Stradicnsš University, Latvia

\begin{abstract}
Young unemployed people have comprised one of the significantly largest groups of the unemployed people in Latvia in recent years. One of the reasons why young people have difficulty integrating into the labour market is the "expectation gap" that exists in the relations between employers and the new generation of workers. Employers focus on capacity-building for employability such individual factors as strength, patience, self-discipline, self-reliance, self-motivation, etc., which having a nature of habit and are developed in a long-term work socialization process, which begins even before the formal education and will continue throughout the life cycle. However, when the socialization is lost, these habits are depreciated faster than they can be restored.

Currently a new generation is entering the labour market, which is missing the succession of work socialization. Factors, such as rising unemployment and poverty in the background over the past twenty years in Latvia have created a very unfavourable employability background of "personal circumstances" and "external factors", which seriously have impaired formation of the skills and attitudes in a real work environment. The study reveals another paradox - the paradox of poverty. Common sense would want to argue that poverty can be overcome by the job. However, the real state of affairs shows that unfavourable coincidence of the individual, personal circumstances and external factors leads to deficit of employability capacity and possibility of marked social and employment deprivation.
\end{abstract}

Key words: unemployment, employment, employability, work socialisation, poverty

\section{Unemployment}

Unemployment is complex and one of the gravest problems of Latvia. People become unemployed due to different causes: some lose their jobs because the company goes bankrupt, others because of losing the competition for jobs, others due to their health problems, but in most cases - due to a lack of jobs.

Due to destabilization of the economic process in the country the unemployment rate over the past two years has been among the highest in the European Union. According to EUROSTAT in October of 2010 Latvia has the second highest unemployment rate - 19.4\% (The proportion of job seekers among economically active population (aged 15-74)). Although unemployment rates in 2011 are decreasing, the total number of the unemployed is still high (according to EUROSTAT in the second quarter of 2011 it was 16.1\%; in absolute terms in August - 134,175 people) (http://www.nva.1v/docs/17_4e82f7e2ae 1318.66610138.xls\#'1'!A1).

To be an unemployed for most cases means to reconcile oneself to low living standards and low quality of life, because for the majority of Latvian population the only source of income is salary. Unemployed people, due to lack of financial resources, become receivers of social assistance and beneficiaries or are cared by their relatives.

In terms of poverty level Latvia takes one of the first places among European Union countries (26\% of the population, according to EUROSTAT for 2008). Number of people who, in search for better life, every year leave the country is increasing. Very often they leave the country for ever and move to live in other countries. Leading researchers and experts have their own assumptions and criteria, as well as sources of information, for determination of the number of emigrants. According to these estimates number of Latvian population

This is an Open Access article distributed under the terms of the Creative Commons Attribution License 2.0, which permits unrestricted use, distribution, and reproduction in any medium, provided the original work is properly cited. 


\section{SHS Web of Conferences}

working abroad oscillates in wide amplitude up to 100 thousand (Informatīvais ziņojums par prognozēm darbaspēka pieprasījuma un piedāvājuma atbilstībai vidējā termiņā, 24. lpp. http://www.lm.gov.lv/upload/darba_tirgus/darba_tirgus/em_zin_prognozes_2010-1. pdf). (According the last data $\sim 200$ 000) (Hazans, M. http://www.delfi.lv/news/ national/politics/petijums-pedejo-11-gadu-laika-latviju-pametusi-200-tukstosicilveku.d?id=40590075).

A significant part of unemployment is the so-called "long-term unemployed" - people who are unemployed for more than a year (31 December, 2010 - 37.9\%). Their number is growing. After the SEA data, in the period from February, 2010 - 31 January, 2011 number of longterm unemployed had almost doubled from 34000 to 64000 people. Among them were $14.3 \%$ of young people aged 15 to 24 years (23 376), including of the age of 18 to 24 years -19 795 persons. In August, $201139.8 \%$ of the unemployed people were out of work from 1 to 3 years, but $4.2 \%$ more than 3 or more years (Bezdarba situāciju valstī. 2011. gada augusts. http: //www.nva.1v/docs/17_4e8bfb4451b6d4.57531298.doc).

However, these figures do not fully reveal a real unemployment situation, since there is no accurate information on unregistered unemployed persons.

As particularly complicated problem in Latvia can be considered the situation of young people in the labour market. After EURSTAT data in 2010 the unemployed were $34.5 \%$ of young people under 25 years of age. The unemployment rate among young persons was higher than the rate among those aged between 25 and 74 in all of the Member States. (EUROSTAT. Table unemployment rates by age and gender.PNG. http: //epp. eurostat. ec.europa. eu/statistics_explained/index .php?title=File: Table_unemployment_rates_by_age_ and_gender. PNG\&filetimestamp=2011050412560).

Latvian Free Trade Union survey reveals:

"In time of economic growth, as well as now, when there is a crisis (2010), many young people are unemployed, and young people without work outnumber older people. Young people are forced out of jobs and then, unfortunately, are often no longer motivated continue to work. And those young people, who work, often do not receive adequate remuneration and are poor. Many are employed illegally, temporarily, in part-time and high-risk or unsafe jobs. Many young people are working unacceptably long hours or non-independent positions. They are offered low wages, poor working conditions, lower social security or its absence" (ESF projekts "Latvijas Brīvo arodbiedrību savien̄̄bas administratīvās kapacitātes Stiprināšana "Cien̄̄gu darbu jauniešiem!" 2. daļa. Ekspertīze par Sociālo jomu un darba tirgus attīstību. 2010.gada septembra ziņojums, 3. lpp. http://www . Ibas . lv/upload/stuff/201010/ lbas_ekspertize_jauniesu_nodarb_300910.pdf).

Returning of unemployed people to the labour market is determined by different circumstances. In addition, - the longer a person is unemployed, the more difficult it is to find a job.

The labour market of Latvia has a lot of problems, but the views of employers, employees and institutional agents (subjects) on them differ substantially. Employers are frustrated with the opportunity to find their compliant workforce, employees are dissatisfied with the jobs offered in labour market, but the institutional agents cannot see the opportunities and methods for bringing nearer positions of employees and employers. Recently, institutional agents have become increasingly frustrated with the quality of various specialists prepared by universities and vocational training institutions for the labour market (Rivža, 2007).

Long-term unemployment has both subjective and objective causes. It is believed that in Latvia exists structural unemployment, when the offer does not correspond to the demand, and the main reason is that the skills do not meet the requirements of the market. Such situation can lead to both the inability of workers to acquire new skills and move from one sector to another (retraining), and the lack of regional mobility (http://www.swedbank. Iv/lib/lv/Swedbank_Petijums_13-12-2010.pdf).

It is understandable that appropriate education and vocational training are the determining factors for competition in the labour market, but it does not necessarily settle the issue "to be or not to 


\section{Int. Conf. SOCIETY. HEALTH. WELFARE; Congr. of Rehabilitation Doctors of Latvia}

be unemployed". Arguing from the perspective of non-compliance of skills, the institutional agents' dissatisfaction with the quality of various specialists, although not entirely without foundation, is not sufficiently reasoned, if it is not clearly stated what deficit of skills are concerned.

Mutual dissatisfaction of employers and employees is more likely not only the problem of acquired knowledge at school, but suggests that there are other, no less important, factors. If everything depended only on acquiring of "pure knowledge" and practical techniques, the employment problem would be solved much easier. But it is not so. It is obvious that low percentage of the unemployed people, who have finished the retraining programmes, return to the labour market.

According to the authors of this article unemployment problem and quality of workforce should be analysed from the point of view of employment and employability. Analysis of observations and case studies reveals that people, who have not had regular job for a long time, very often experience an ambivalent condition between their desire and abilities; on one hand they would like to work regularly and organize their life. However, on the other hand - they cannot be employed. In addition to the fact that they lack a concrete, acquirable skill, they have also lost or have not acquired essential human quality characterizing capacity of employability or ability to work; among them "a habit to be employed", ability "to fall into the rhythm of work - endurance", "to be in the relations of co-operation and subordination", "creativity, self-initiation, determination and discharge of duties".

"Pure knowledge", acquired at school, itself is not always the decisive factor for employment opportunities. Employability capacity is also affected by factors such as strength, patience, selfdiscipline, self-reliance, self-motivation, etc., factors that have a nature of habit and which are developed in a long-term work socialisation process, which begins even before the formal education and will continue throughout the life cycle. However, when the socialization is lost, these habits are depreciated faster than they can be restored.

\section{Employment and employability}

Registration of the unemployed in Latvia has taken place since 1992 with the entry into force of the law "On Employment". Therefore unemployment research in Latvia has a short history. In labour sociology, employment problems in Latvia have been studied more carefully only within the last 10 years (Keune, 2000; Trapenciere, 2005; Rivza, 2007; Korolova, 2007, etc.).

Recently, among Latvian economists, personnel experts, entrepreneurs and education specialists more and more discussions take place on the employment and employability, especially when it comes to youth unemployment problems. The concept of employability has historically been widely covered in the literature describing the changes in the labour market in the European countries at different times and in different contexts. Latvian labour sociology has not given adequate theoretical interpretation of "employability". Employability is mainly related to the education and qualifications.

Searching for the causes of the difficulties the unemployed experience, competing in the labour market, studies mainly highlight the subjective factors. Employers and recruiters often claim that a large number of unemployed people cannot work, do not want to work and are not ready to work. Particular difficulties in joining the labour market are experienced by those who are without work in the long term. The discussions on unemployment and its causes are characterized by highly critical attitude to the unemployed. Most commonly subjective faults of the unemployed themselves are emphasized: willingness or unwillingness to work. Such interpretation of the causes of unemployment is characterized rather by intolerance to unemployed than a realistic understanding of the problem. Although studies do not use the concept of employability, it is clear that they do discuss specifically employability. Here you can drag a historical parallel with the understanding of employability we bring together in the $20^{\text {th }}$ century in the United Kingdom. (Dichotomic employability - emerging at the beginning of the $20^{\text {th }}$ century in the UK and the US. Gazier describes this formulation of the concept of employability as 'dichotomic' due to its focus on the opposite poles of "employable" and "unemployable", initially with little or no gradation: "employable" referring to those who were able and 


\section{SHS Web of Conferences}

willing to work; "unemployable" referring to those unable to work and in need of "relief" (McQuaid, Lindsay, 2005; 200).

Evolution of the employability conception, revealed in the theoretical literature, in the period since the last century till nowadays, shows that employability includes a wide range of factors. It has three main interrelated components, or sets of factors that influence a person's employability: individual factors; personal circumstances; and external factors. "Personal circumstances", includes a range of socioeconomic contextual factors related to individuals' social and household circumstances. "External factors" include those influencing a person's employability, such as labour demand conditions and enabling support of employment - related public services (McQuaid, Lindsay, 2005).

Such individual factors of employability as essential attributes - basic social skills; honesty and integrity; basic personal presentation; reliability; willingness to work; understanding of actions and consequences; positive attitude to work; responsibility; self-discipline. Personal competencies; proactivity; diligence; selfmotivation; judgement; initiative; assertiveness; confidence; act autonomously (McQuaid, Lindsay, 2005) should be considered as basic factors of employability capacity, and are forming and developing in the course of work socialisation. In addition, an important role is played by circumstances in which work socialization occurs. Among others - work culture and work understanding play a significant role. According to McQuaid and Lindsay (2005) work culture: the existence of a culture in which work is encouraged and supported within the family, among peers or other personal relationships and the wider community.

\section{Work socialization}

In the process of socialization the individuals acquire models of behaviour, social norms and values, necessary for their functioning in the society. Work socialization is integrated in the process of general socialization. However, work socialization can be considered as relatively independent component of socialization as well, aim of which is to develop labour skills as a habit, acquire behavioural patterns and work culture in compliance with the work environment.

Based on the findings of the European longitudinal research study Work Socialization of Youth (WOSY), socialization for work concerns attitudes, values, and cognitive capacities acquired before entering the working world. Socialization by work, on the other hand, reflects the personal qualities that develop in young adults confronted with the working world (Cohen-Scali, 2003). Socialization for work appears to be a long process which has its origins in childhood, becomes more and more complex and is enriched throughout adolescence and adulthood, notably through professional training courses which are vectors of diffusion of culture and new values (Cohen-Scali, 2003).

In the area of employment in Latvia, significant changes have taken place in the recent 20 years. A principal difference lies in the issue of work status: in the period of soviet ideology in Latvia not only rights to work existed but also compulsory duty to work. Moreover, work was considered to be the "matter of honour, fame and heroism", but unemployment was unfamiliar, even not understandable, since work was interpreted as "the source of wealth". In present free market conditions in Latvia, work has gradually become a subject of a deal between an employer and employee, as relations of buying and selling in conditions of competing interests.

The nature of work is changing rapidly, too: appearance of new technologies supersede the jobs previously performed by people. Within a short time - only 20 years - certain types of work, and even professions, have become history. The understanding and definition of work have changed. Latvian people have to face the phenomenon when not every job is defined as work, as meaningful and honourable occupation for which it is possible to get a decent salary. The idea that "work is a source of wealth" for the generation that has grown up in post-Soviet Latvia, is hardly understandable. This generation better understands the idea that "money is the source of all the wealth and possibilities".

Changes in the nature of work, spread of unemployment and of the lack of work have enhanced in people a sense of instability and unpredictability. But at the same time, along with new work culture and 


\section{Int. Conf. SOCIETY. HEALTH. WELFARE; Congr. of Rehabilitation Doctors of Latvia}

new relations, in the labour market dominating is the demand for professionals with new knowledge, skills and competencies, for professionals with high employability capacity.

Researching mutual expectations of employers and employees, data of the National Statistics Bureau and EUROSTAT have been used, and research summaries of the National Employment Agency, as well as results of 3 interrelated studies on youth employment, carried out in the Social Work Department of RSU: Z.Puncule, op. O.Bruvers. "Youth awareness of work and the ability to successfully enter the labour market"; L.Vilka, A.Vilks. "Satisfaction of the social needs of children from families with low income: Comparison between the city and the countryside"; O.Plaksina, L.Vilka. "Job skills for youth in high school".

The studies involved 392 young people aged 15 to 25 (in the following age groups: $\mathrm{n}=192$, $18-20$ yrs, $\mathrm{n}=100,18-25, \mathrm{n}=100,15-18 \mathrm{yrs}$ ). Opinions of the young people were studied with the help of questionnaires.

For a more complete picture of how young people evaluate their work, 16 interviews with young people were also carried out. At the time of interviews, 10 young people were working, 4 of them returned to work after more than a year's break. Six young people had recently lost their jobs again. Eight interviewees had also their own families with children.

Employers' opinion has been found out with partly structured interviews. Sixteen experts - work supervisors from several economic areas (construction works, agriculture, transport, IT technologies, trade and service) - had experience in formation of work relationships with young people within the recent 3 years. Employers belonged to the middle-aged generation - at the age of 35-45.

Studies were carried out in Riga and two Latvia towns with their surrounding rural areas.

The above studies is the basis for this study on the role of subjective factors of youth employability in the employment relationship, mutual expectations of employers and young employees, and business readiness to promote the socialization of young people at work.

The study used "cognitive dissonance" factor (what I think of myself; what others think of me; what I think about what others think of me), which was reorganized according to the study idea: What do I think of me as an employee? What do other people think of me as an employee? What do I think, what an employer should be like?

In this case, study was initiated by the analysis of experts' - the employers' views. Based on semistructured interview responses, signs were identified that characterize a youth - a potential employee, their "ideal image", and expectations from the experts' perspective. Experts' idea on "the expected employee" then was compared with the perceptions of "ideal employer" from the young people's point of view.

\section{The research results}

Experts had a similar view on the fact that the skills, the ideal young employee should have, can be divided into three groups: 1) skills, including the individual quality of the personality, 2) social skills (ability to communicate, solve problems, apply them in different situations) and 3) technical skills (working with the IT, skills of driving).

It should be noted that all the experts, on the issue of "ideal" employee, as the most significant features re-emphasized the social skills and the individual qualities of the personality: "We give priority to social skills and personal attributes"; "My business depends on personal skills such as responsibility, flexibility, ability to interact with others and discipline".

At the same time experts have stressed the need for "the ability to work in a team, discipline, decision-making skills, initiative - unfortunately, young people do not possess these skills".

Employers - experts have similar opinions on the fact that the generation that is now entering the labour market has significantly changed its understanding of the work, compared with the period of about ten years ago. In terms of what exactly has changed, the majority of experts supported the view that young people as the main point in work see profit and material benefit. "At present young people are 


\section{SHS Web of Conferences}

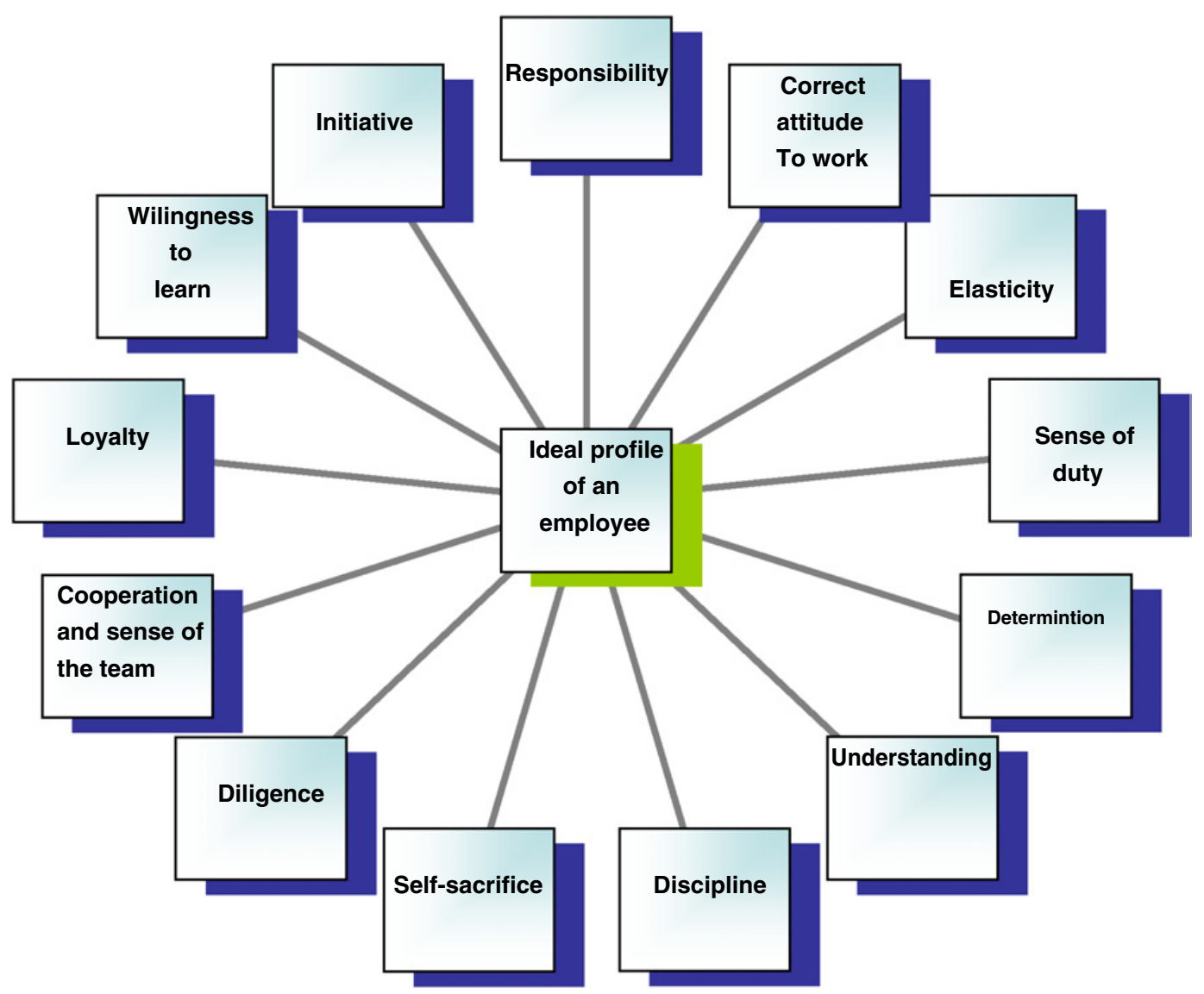

Figure 1. Ideal profile of an employee.

quite ambitious, ...they tend to set excessively high standards to employer, mainly in terms of pay, but not always adequately assessing their own real capabilities and abilities in relation to the requirements".

Since the experts were convinced that people's awareness of work has changed, it was important to find young people's own understanding of work. A questionnaire was distributed in which respondents initially had to describe in one sentence, what they understand by the word "work". In other words, young people gave their own versions of the definition of "work". Using content analysis, one common definition was set up: the work is regular, paid performance of duties, using personal skills and knowledge, resulting in receipt of remuneration.

Opposite the ideal profile of an employee, resulting from the expert interwievs, young people think that the employer wants to see the following qualities in the employee:

$\mathrm{n}=100$

age $=$ m 18-25.

Comparing the work definition given by young people and views on the ideal profile of an employee, it cannot be overlooked that young people are highly pragmatically oriented. Remuneration as the most important sign from the point of view of youths has been reasonably attributed to productivity. Thus, employees who are focused on results have greater possibilities to receive higher wages. Significantly less importance young people attach to attitudes.

In response to the question "what do young people expect from an employer?" young people reaffirm their pragmatism, in the first place placing "competitive salary" (53\%). 
Int. Conf. SOCIETY. HEALTH. WELFARE; Congr. of Rehabilitation Doctors of Latvia

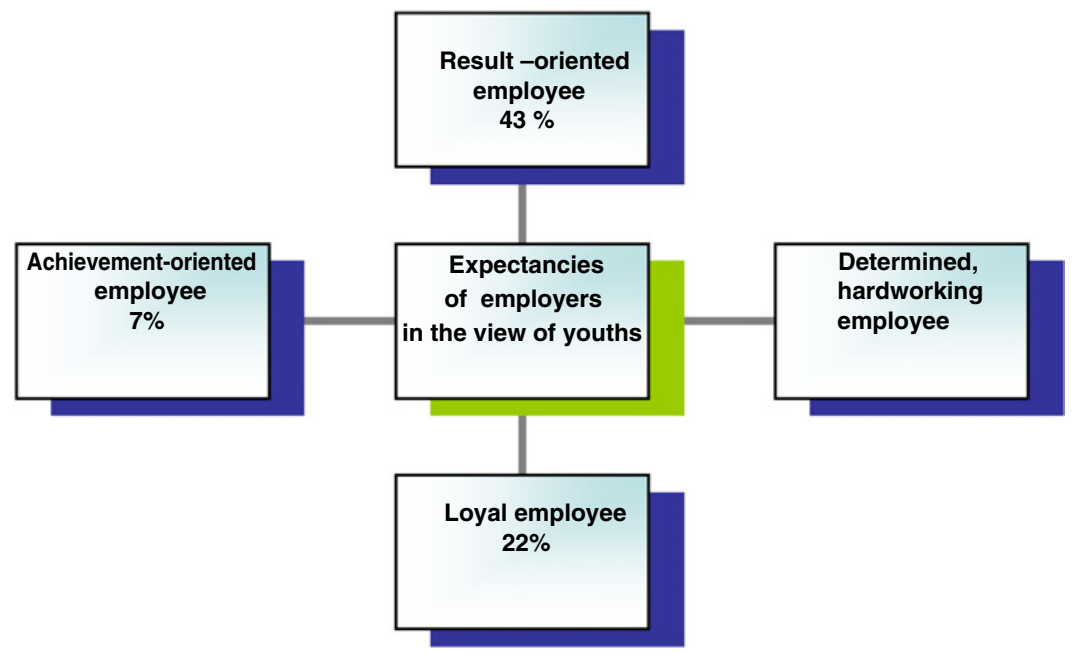

Figure 2.

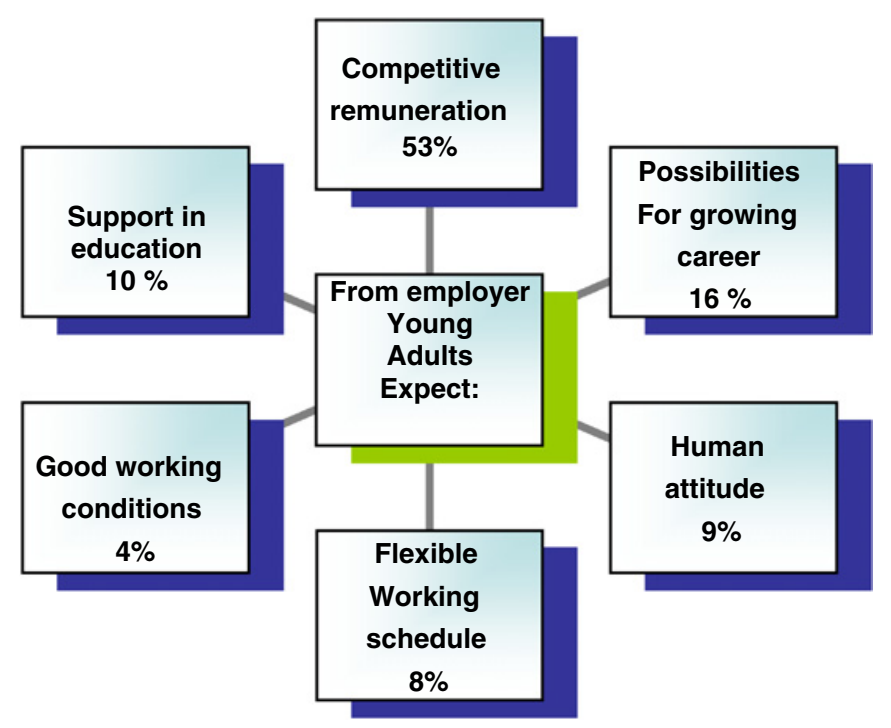

Figure 3.

$$
\begin{aligned}
& \mathrm{n}=100 \\
& \text { age }=18-25 .
\end{aligned}
$$

To compete successfully in the labor market, the youths claim that one should possess characteristics such as sense of responsibility, sense of duty, determination, integrity, punctuality.

$\mathrm{n}=100$

age $=18-25$.

The answers show that in general young people understand that individual personality qualities play an important role in competition in the labour market, and to some extent it corresponds to employers' expectations. However, this understanding is rather "should be" than actual practice. When asked, for what the employer pays wages, young people give clear answer: for work (paid duties).

The majority of the youths involved in the research $(81 \% ; \mathrm{n}=292)$ considered themselves to be ready for work relations. 


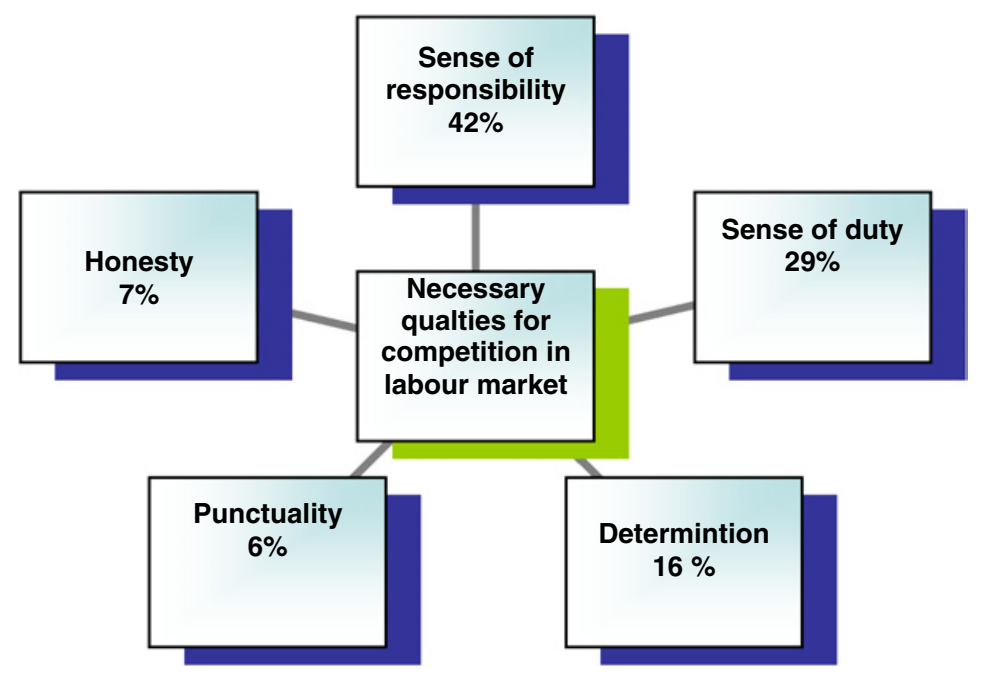

Figure 4.

Competing for job position, a young person with a pragmatic orientation in an interview with a potential employer might say: "I possess sufficiently high sense of responsibility, I have a sense of duty and enough ambitions. If you pay good salary, do not doubt the results".

However, asked about future intentions, majority of the surveyed 200 respondents answered: "I'll go abroad" $(60.4 \%)$. More than half of young people choose to work abroad, even in spite of the fact that there they usually have to work in simple professions or as service and sales staff. Motivating factor to work abroad - sufficiently significant and favourable wage differentials compared with Latvia.

Research of expectations, that exist between young employees and employers, leads to the conclusion that the integration of young people in the Latvian labour market has a serious obstacle - "expectation gap" (expectation gap - the difference between mutual expectations, deviation) - or expectation gap of employability.

Employability "expectation gap" is characterized by the following factors:

- deficiency of the individual factors of employability in young people,

- focus of employers on individual employability factors as priority for the personnel selection,

- differences in understanding of work between young people and employers,

- different objectives in the employment relationship: focus of an employee on salary, while employers subordinate the salary to the individual personality qualities: ambition, sense of responsibility, good attitude and loyalty to the employer, etc. (employers, through unclearly defined requirements e.g., "the right attitude towards work", often justify their reasons why not to pay higher salaries),

- employers have the general stereotype belief that young people are not mature enough for serious employment relationships, are not serious, not enough responsible and hardworking (a widespread view among the medium and elder generation), so employers often do not trust them,

- high ambition and boldness of young people, that from the point of view of the employer is often not justified by knowledge and skills,

- employers are focused on experienced workers, but young people lack work experience,

- employers rather "see" skills shortage than notice the inherent advantages of young people: ambition, boldness, and their skills and knowledge resources they certainly have - for example, in use of information technology young people, who are familiar with it from elementary school, are much more knowledgeable than many of the employers, working in very responsible sectors. 
Int. Conf. SOCIETY. HEALTH. WELFARE; Congr. of Rehabilitation Doctors of Latvia

Set of skill components put forward by employers for young people (Figure 1) fall into the category of skills, which appear in a long-term, determined by many factors, work socialization process. Attitudes, values and habits are developed (internalized) in interaction with the work environment, learning the appropriate samples of behavior.

The necessary preconditions for work socialization are job opportunities in real work environment, secondly, - mentoring. In this respect, Latvia has number of serious problems. First, companies are reluctant to recruit young people. "Usually, we employ only the children of friends whose request I cannot refuse. But it would be good if the government supported us". "From the business point of view, it is easier to impose extra duties to current employees without additional compensation or for a nominal premium than to hire inexperienced young people". "With young people we have too big problems, further I am considering the possibility not to take young people" that is what the experts believe.

In conversation about the role of "the teacher of work", or mentoring, when young people start their working life, some experts, in general, are quite radical: "I believe them to be brought up by his father and mother, I do not have time for such things, and it's not my job. Of course, due care and diligence at work I demand, but if we cannot agree - good-bye, but to bring them up - no".

Work socialization is primarily considered a family responsibility: "If in the family honest work is value, then a youngster also learns a positive and "correct" attitude (our underlines L.V., I.P.) to work from an early age". "Young people need to understand that work is not always interesting and exciting, as it is also a part of routine, responsibilities and duties to be performed in accordance with the job description".

\section{Closing}

Currently the labor market is being entered by a new generation, which is missing the assignment of work socialization. Their childhood, adolescence and early adolescence have passed in the period of time when transformation of the previous employment relationships was taking place. In the nineties, in Latvia, previous work socialization system slowly disintegrated, but formation of the modern labour relations and their adaptation to the nature of the labor market were proceeding slowly. In addition, factors such as rising unemployment and poverty over the past twenty years have created a very unfavorable background of employability "personal circumstances" and "external factors", which seriously have impaired the formation of skills and attitudes in real work environment.

From the socialization perspective, particularly complex has been time since the mid-nineties. According to data of the review of 1995 on population development in the 1993-1994, in poverty and below the poverty line lived about $70 \%$ of Latvia residents, $10 \%$ - within the limits of subsistence, but 20\% - above the subsistence level (ANO Latvijā: Pārskats par tautas attīstību: 6. nodaļa. (http://www.un.1v/down/1995/chapter6.htm). In 1996 it was detected that 289.4 thousand households with children were poor. Around 58\% of households in both 1996 and 1997 assessed their economic situation as bad or very bad.

Data of 2001 showed that still one-third of children lived in poverty, while $13 \%$ lived in poverty in which children were undernourished and inadequately healthy. Overall, children make up about half of the total poor population. $1 / 5$ of households live in poverty. In age group up to 10 years $-48 \%$, but in the age group of 10 to 19 years $-44 \%$ of young people live in poverty. (Sociālās atstumtības riska faktoru identificēšana trūcīgo ǵimeņu bērniem, 2002).

Unemployment - poverty and means of livelihood from the social security payments form a kind of "magic triangle" - "poverty trap", where a large number of Latvian families are forced to accept their miserable situation and develop a "survival behaviour", which gradually becomes a forced lifestyle. 


\section{SHS Web of Conferences}
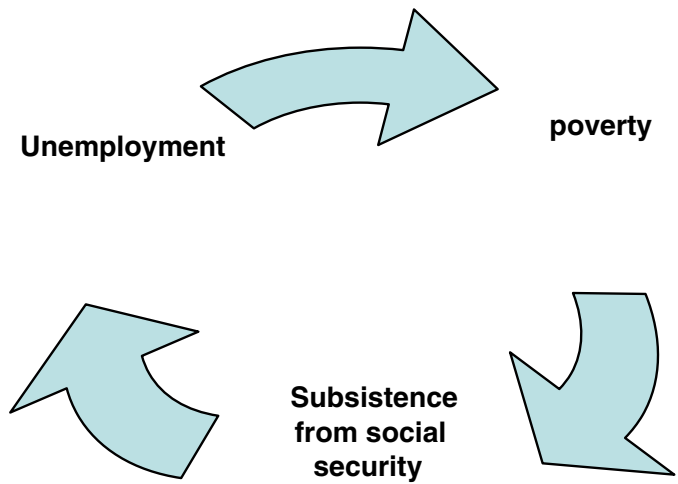

payments

Externally, this survival way of life may look like people's unwillingness to work and live better. However, it would be perfunctory sentence. Very often the truth is different. Living from day to day by the rules of survival, families gradually are forced to face a marked condition of social deprivation. Among other things, the study also revealed that a significant proportion of the surveyed and interviewed young people considered themselves as "lost generation".

The "right attitude factor", advocated by employers, also includes some of the answers, why it is so difficult for Latvian youth to find a place in the labour market. The fact that adolescents and young people can learn from the "survival behaviour" models in their families, often leads to the conclusion that "honest work" cannot ensure decent living conditions. Axiology of previous generations - work is a source of wealth - completely changes for obvious reasons: there is no job! Only money can save from deprivation and poverty. Only money makes it possible to "redeem oneself" from the poverty trap. It may be considered that employability "expectations gap" between employers and employees is formed objectively and that young people will not be willing to do any job on any terms.

The study reveals another paradox - the paradox of poverty. Common sense would want to argue that poverty can be overcome by the job. However, the real state of affairs shows that unfavourable coincidence of the individual, personal circumstances and external factors of the employability leads to employability capacity deficit, and possible marked social and employment deprivation and the sense of alienation in total.

\section{References}

[1] Vipule, S. Bezdarba attīstība un to ietekmējošie faktori Latvijā. http://www . bank. Iv/publikacijas/averss-un-reverss/1999-6/bezdarba-attistiba-un-toietekmejosie-faktori-latvija/4660

[2] ANO Latvijā: Pārskats par tautas attīstību 1995. http://www.un.lv/down/1995/ chapter7.htm

[3] Pārmaiņas Latvijā 1990-2005. Statistikas datu apkopojums. http://webcache. googleusercontent . com/search? q=cache : 2yyZstNAgs J : www . politika . 1v $/ \% 3 \mathrm{Fid} \%$ 3D $111237 \% 26 l a n g \% 3 D l v+$ bezdarba + statistika $+1992+2010 \& c d=8 \& \mathrm{hl}=1 \mathrm{v} \& \mathrm{ct}=\mathrm{clnk} \&$ $\mathrm{gl}=\mathrm{lv}$

[4] Latvijas tautsaimniecība: MAKROEKONOMISKAIS APSKATS. http://www.em.gov.lv/ images/modules/items/tsdep/makro_46/makro46_LV.pdf

[5] Sociālās atstumtības riska faktoru identificēšana trūcīgo ǵimeņu bērniem (2002) Rīga: LU Filozofijas un socioloğijas institūts.

[6] Latvijas statistika. Nodarbinātība un bezdarbs. http://www.csb.gov.1v/statistikastemas/nodarbinatiba-un-bezdarbs-galvenie-raditaji-30263.html 
Int. Conf. SOCIETY. HEALTH. WELFARE; Congr. of Rehabilitation Doctors of Latvia

[7] Forrier, A. (2003) The concept employability: a complex mosaic. Int. J. Human Resources Development and Management. Vol. 3 (2). http://www.ouderenenarbeid. be/Documenten/artikel\%20IJHRDM.pdf

[8] McQuaid, R.W., Lindsay, C. (2005) The Concept of Employability. Urban Studies. Vol. 42 (2).

[9] Cohen-Scali, V. (2003) The Influence of Family, Social, and Work Socialization on the Construction of the Professional Identity of Young Adults. Journal of Career Development. Vol. 29 (4).

[10] EUROSTART Unemployment statistics. http://epp.eurostat.ec.europa.eu/ statistics_explained/index.php/Unemploymenttatistics

[11] http://www.social.1v/portal/nodarbinatiba/aktualitte/1302-strauji-audzisilgstoso-bezdarb nieku-skaits

[12] http://www.swedbank.1v/lib/lv/Swedbank_Petijums_13-12-2010.pdf

[13] Rivža, P. (2007) Darba tirgus pētījums Latvijas un tās reǵionu darba tirgus specifiskās problēmas. Jelgava: LR Labklājības ministrija.

[14] Korolseva, I. (2007) Darba tirgus pētījums Jaunieši darba tirgū: situācijas un nodarbinātību ietekmējošo faktoru analīze. Rīga : SIA "Sociologisko pētījumu institūts".

[15] Keune, M. (2000) Poverty and the labour market in Latvia. Rīga: Labklājības ministrija.

[16] Trapenciere, I. (2005) Poverty in Latvia. Project Poverty, social assistance and social inclusiondevelopments in Estonia and Latvia in a comparative perspective. Fafo.

[17] Вайсбург, А.В. (2009) Проблембі ппофеционалбной цоциализации цоциологов в регионе. Регионология, 1. http://regionsar.ru 